\title{
ANALYSIS OF MASONRY INFILLED RC FRAME STRUCTURES UNDER LATERAL LOADING
}

MIRCEA BARNAURE - Assistant Lecturer, $\mathrm{PhD}$, Technical University of Civil Engineering, Faculty of Civil, Industrial and Agricultural Buildings, e-mail: barnaure@yahoo.com

DANIEL NICOLAE STOICA - Associate Professor, PhD, Technical University of Civil Engineering, Faculty of Civil, Industrial and Agricultural Buildings, e-mail: stoica@utcb.ro

\begin{abstract}
Partition walls are often made of masonry in Romania. Although they are usually considered non-structural elements in the case of reinforced concrete framed structures, the infill panels contribute significantly to the seismic behaviour of the building. Their impact is difficult to assess, mainly because the interaction between the bounding frame and the infill is an intricate issue. This paper analyses the structural behaviour of a masonry infilled reinforced concrete frame system subjected to in - plane loading. Three numerical models are proposed and their results are compared in terms of stiffness and strength of the structure. The role of the openings in the infill panel on the behaviour is analysed and discussed. The effect of gaps between the frame and the infill on the structural behaviour is also investigated. Comparisons are made with the in-force Romanian and European regulations provisions.
\end{abstract}

Keywords: numerical modelling, in-plane deformation, gap, diagonal strut, openings

\section{Introduction}

In Romania, reinforced concrete (RC) frame structures have been and are still commonly used for small and medium rise residential and office buildings. For this type of establishments, exterior walls and many interior partitions are made of masonry, creating a system that often provides a cost-effective solution for thermal and sound insulation purposes.

For the structural design of such buildings, the interaction between the infill panels and the frames is often ignored. The masonry walls are usually just considered non-structural elements, while the vertical and horizontal loads are only carried by the RC frames. Neglecting the influence of the infill panels on the structural behaviour may underestimate the stresses that develop in some of the elements under earthquake loading. Such an oversight could lead to premature failures and increases life safety risks.

When examined relative to the bare frame structure, the most important effects of the interaction between the infill panel and the frame are as follows: an increase in lateral stiffness, stiffness irregularities of the building in plan and/or elevation, local effects (mainly changing forces and moments in nearing columns and increased stresses in the masonry).

The increase in lateral stiffness leads to lower period for the fundamental mode of the building, which could, depending on the design response spectrum, correspond to higher peak acceleration.

The stiffness irregularities give rise to a concentration of forces in the perimeter elements (due to a higher distance between the centres of mass and rigidity) or at soft-story levels.

Local effects may not only engender a failure of non-structural partition walls, that is more severe should combined in-plane and out-of plane actions occur, but it can also induce a higher shear in the columns, thereby creating the risk of brittle failure.

Recent earthquake investigations show that the interaction between frames and infill panels should not be neglected. 
Reinforced concrete buildings with masonry infill walls had a very good behaviour during the 2010 Canterbury earthquake $[1,2]$, despite its intensity. Only 7 percent suffered moderate damage, while 3 percent were subject to serious structural damage. Even if masonry infill walls were not a part of the structure of these buildings, they contributed to the global stiffness in the early stages of the strong ground motion. The damage mostly consisted in the cracking of the masonry in the partition walls. In contrast, incipient brittle failure modes of the RC members were very rarely observed. Most of the structures that suffered damage were built before 1970 .

In the 2011 Lorca earthquake [3], some of the buildings that had no effective mechanism to resist lateral loads performed well, and showed damage similar to better designed buildings. Still, many buildings with masonry partition walls suffered serious damage, especially those with asymmetrical horizontal stiffness, akin to the corner buildings of apartment blocks. One of them even collapsed. For other buildings, a soft storey mechanism developed after the deterioration of the ground floor masonry walls. Another type of observed damage comprised of failures of the beam-column joint and shear damaged columns.

In the 2008 Wenchuan earthquake [4,5], many residential and commercial buildings experienced severe damage to the ground floor when less infill walls were at this level as compared to the upper stories. After breakage of the masonry infill walls at the ground floor and prior to the flexural yielding of the columns, the stiffness of the first story significantly reduced and suddenly overloaded the first story columns in shear. This led to the brittle failure mechanism. In some cases, the soft storey mechanism led to building collapse. In the case of infill walls made with hollow tiles, the damage only occurred in the walls, with bricks breaking under compression stresses and the parts of the wall collapsing. In the case of solid bricks, damage was mainly seen in the walls, but also in the columns. The columns located between windows were particularly damaged, as the short column behaviour led to high shear deformations.

Experimental research investigations [6-8] confirm these possible failure mechanisms.

It is clear that only if the infill is separated from the frame and a sufficient gap exists, then it can be considered that the frame and the panel do not interact. This solution is rarely used in common practice due to the difficulties related to connecting the walls to the frame. Out-of plane loads need to be withstood, while allowing free in-plane deformations and ensuring a good thermal and sound insulation. Moreover, if there is a gap only at the top of the wall, between the infill and the frame, a negative effect could occur: the compression strut acts more on the columns, which leads to a faster increase of shear forces [9].

Because of this, the current engineering practice has to take into account the masonry panels when designing RC or steel frames. For the design of new buildings, the Romanian and European seismic codes $[9,10]$ recommend to consider the effect of the masonry infill panels by equivalent compression struts connecting on the joints of the structure.

Even if infilled frames have demonstrated good earthquake-resistant behaviour at times, it is recommended [9] not to consider the possible positive effects of masonry framed panels in the design model. This is because of the uncertainties related to ensuring a good connection between the infill and the frames during construction.

Over the past decades, researchers proposed various models that allow considering the effects of infills. A first class of models [11], generically named macro-models, involved replacing the masonry by an equivalent pin-jointed diagonal strut. The effective width of the diagonal proposed by authors varies from $1 / 4$ of the length [12] to $1 / 10$ of the length [9]. Others [13] proposed a formula where width depends on the panel geometry, varying from $\mathrm{d} / 4$ for square panels to $\mathrm{d} / 11$ for a $5: 1$ panel.

While the single diagonal strut can represent the general behaviour of the building, it cannot describe the local effects resulting from the interaction between the frames and the panel. In 
order to better predict the bending moments and shear forces in the frame members, multiplestrut models were proposed [14-16]. Recent models [17] consist of bi-diagonal compression struts with a central strut element.

A second class of models, generically named micro-models, rely on complex analysis using the finite element method (FEM). These models allow to better represent the interaction between the masonry and the frames and to identify all modes of failure and all local effects. They are though more difficult to implement as they require high computational time. The first models [18] used link elements in the contact region, which can transmit compressive forces but not tensile ones. Other models [19] also use plastic theory related to the modes of failure. More recent models [20] use the frame-infill separation criteria to find the length of contact between the infill and the frame for a certain loading pattern. Finally, some models [8, 21-23] simulate the behaviour of masonry infilled RC frames using a combination of discrete and smeared crack elements for the $\mathrm{RC}$ frame and the infill panel.

This paper examines the structural behaviour of masonry infilled RC frames under in-plane loading. A FEM modelling approach is adopted, with the robustness of the numerical results being ascertained across several alternative configurations. Our focus lies on the following aspects. First, the main differences in the structural behaviour of the bare and the infilled frames are identified. Second, the influence of any physical gap between the frame and the infill is evaluated. Third, the ability of the diagonal frame model to replicate the actual behaviour is closely examined. Fourth, the impact that any openings in the infill might have on the structural response is measured. Last, the soft storey mechanism is analysed.

Previous literature points to the existence of five ways in which masonry infilled frames may fail: corner crushing, diagonal compression, sliding shear, diagonal cracking and frame failure $[24,25]$. Crushing of the infill at the corners occurs when the masonry used has low compressive strength. Diagonal compression results when the infill is relatively slender and failure stems from out-of-plane buckling of the infill. Horizontal sliding shear is associated with strong frame and weak mortar joints. Diagonal cracking often happens if the infill has high strength and the appearance of the first two failure modes is prevented. Frame failure corresponds to the development of plastic hinges in the columns or in the beam-column connections, when the infill is very strong. The numerical models put forward in this paper are evaluated based on their ability to predict some of these failure modes.

\section{Numerical models considered}

A four storey single span frame structure with reinforced concrete members and masonry infill is analysed. The FEM modelling is conducted using the SAP2000 software.

The values chosen for the beam length and the storey height are $410 \mathrm{~cm}$ and $300 \mathrm{~cm}$ respectively. The reinforced concrete elements (columns and beams) are modelled using frame elements while the infill is modelled using shell elements.

The concrete class is $\mathrm{C} 20 / 25$ [26] and the reinforcement type is PC52 ( $\left.\mathrm{f}_{\mathrm{yd}}=300 \mathrm{MPa}\right)$. The beams are $30 \times 45 \mathrm{~cm}$, with $A_{s}=A_{s}{ }^{\prime}=3 \mathrm{~d} 20$ reinforcement. The columns have a $40 \times 40 \mathrm{~cm}$ section with $4 \mathrm{~d} 25$ (corners) $+4 \mathrm{~d} 20$ (intermediate) reinforcement.

By assumption, the infill is made with $30 \times 15 \times 10$ bricks. The Young modulus was considered $\mathrm{E}=$ $3600 \mathrm{~N} / \mathrm{mm}^{2}$ corresponding to masonry with strong mortar [27]. The compressive strength of masonry was computed in accordance with current European regulations [28] for two scenarios. For hollow bricks with $\mathrm{f}_{\mathrm{b}}=20 \mathrm{MPa}$ and $\mathrm{f}_{\mathrm{m}}=15 \mathrm{MPa}$ mortar, $\mathrm{f}_{\mathrm{k}}=8.3 \mathrm{MPa}$. For solid bricks with $\mathrm{f}_{\mathrm{b}}=30 \mathrm{MPa}$ and $\mathrm{f}_{\mathrm{m}}=15 \mathrm{MPa}, \mathrm{f}_{\mathrm{k}}=13.4 \mathrm{MPa}$. 
The connection between the frame and the infill is modelled using nonlinear gap elements, which allow compression and shear but not tension forces. This type of connection elements also allow to assume that a physical gap exists between the elements and while this gap is not closed due to the deformation of the structure, no interaction occurs.

Nonlinear hinges are assigned to the beams and frames ( $\mathrm{M}$ for beams, P-M for columns).

The vertical and horizontal loads are applied as distributed on each beam. The chosen value for vertical loads at each level is $50 \mathrm{kN} / \mathrm{m}$. The lateral forces have an inverted triangular distribution.

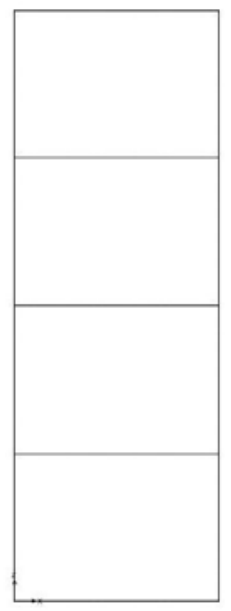

a. Bare frame

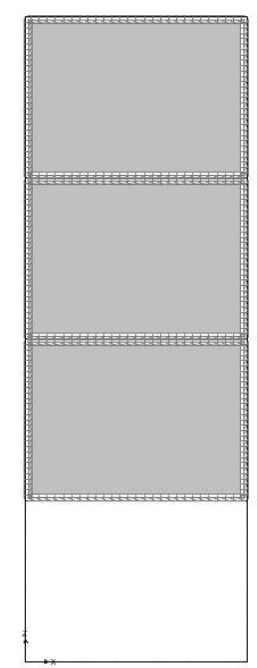

e. Soft storey

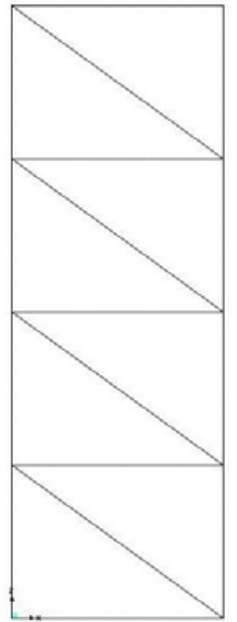

b. Diagonal frame

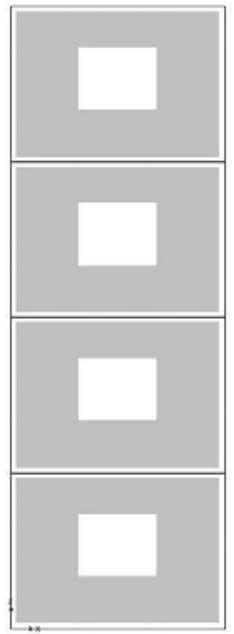

f. Window opening

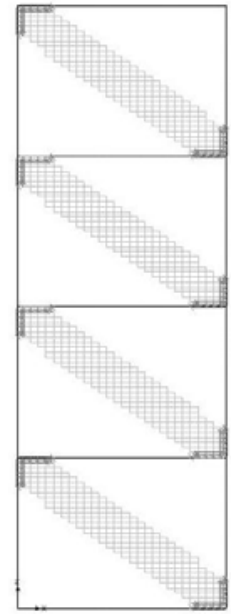

c. Diagonal shell

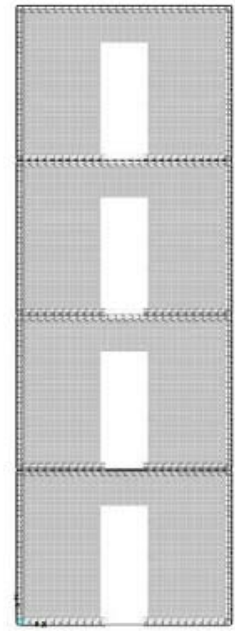

g. Central door opening

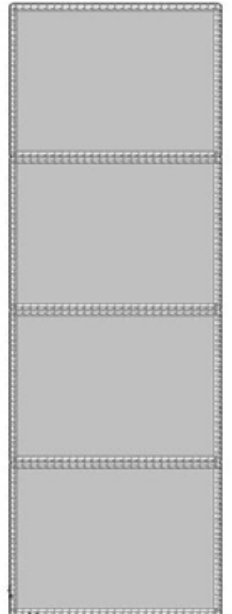

d. Full infill

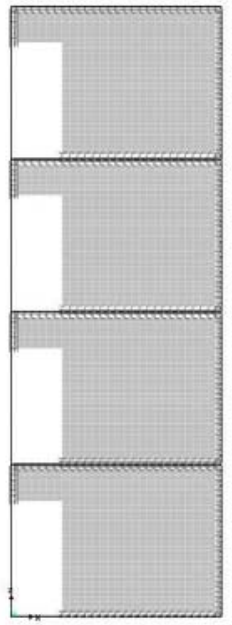

h. Side door opening

Fig. 1 - Configurations considered for the numerical models

Several configurations are analysed as shown in figure 1.

The first configuration corresponds to the bare frame structure, where the existence of the infill is ignored. In the second configuration, the infill is considered by means of a pin joined diagonal frame. In the third configuration the infill is modelled with shell elements but only on the area nearing the compressed diagonal. In the fourth model shell elements are used across a full infill.

The fifth configuration has full infills in the upper storeys while at ground floor level only the bare frame is considered. This model corresponds to the typical case of buildings where the presence of parking or commercial areas at ground floor level leads to less masonry exterior and partition walls.

For the last three models, window $(150 \times 120 \mathrm{~cm})$ and door $(90 \times 220 \mathrm{~cm})$ openings are considered at all levels. 


\section{Comparison between the bare frame and the infilled frame behaviour}

For the bare frame model, the nonlinear static pushover analysis shows that increasing lateral loads leads to development of plastic hinges at the ends of the beams and at the base of the columns before reaching the structural capacity.
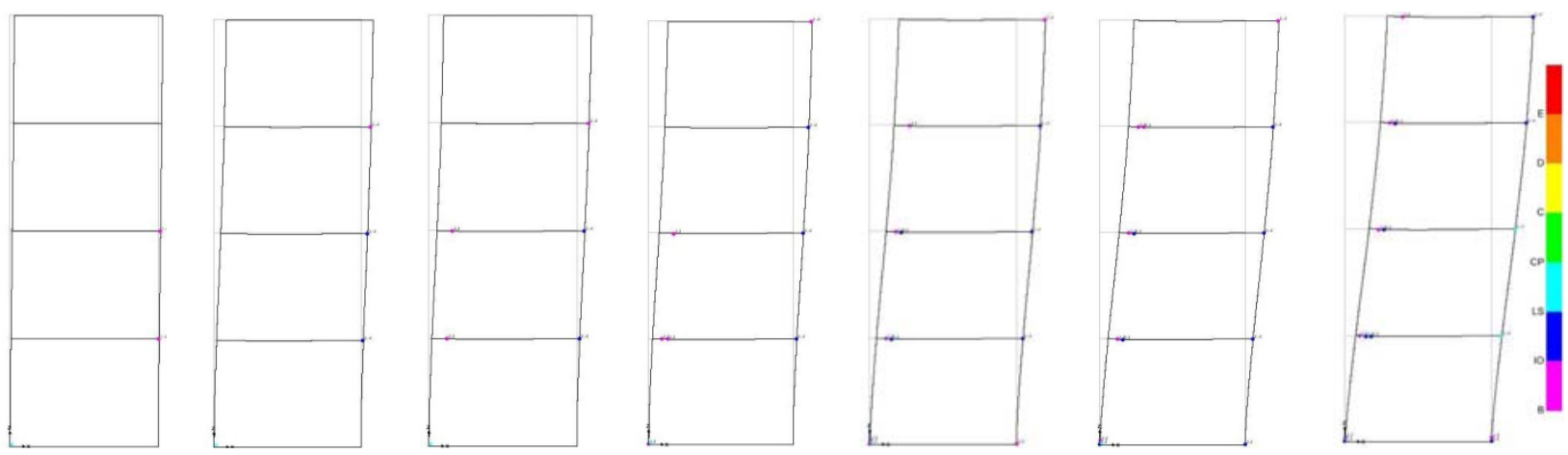

Fig. 2 - Development of plastic hinges in the RC elements for the bare frame model

For the full infill model, the behaviour is different. The analysis shows that increasing lateral loads leads to development of plastic hinges only in the columns.
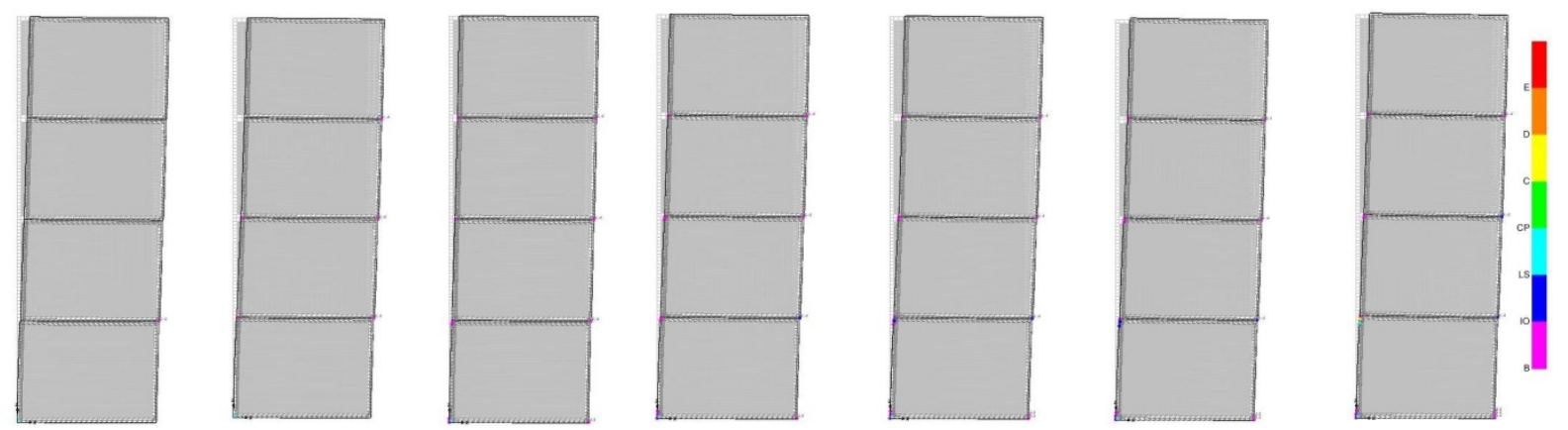

Fig. 3 - Development of plastic hinges in the RC elements for the full infill model

This can be explained by the fact that compressive stresses that develop in the infill panel act as a diagonal and the flexural behaviour of the members is replaced by a compression - tension behaviour.
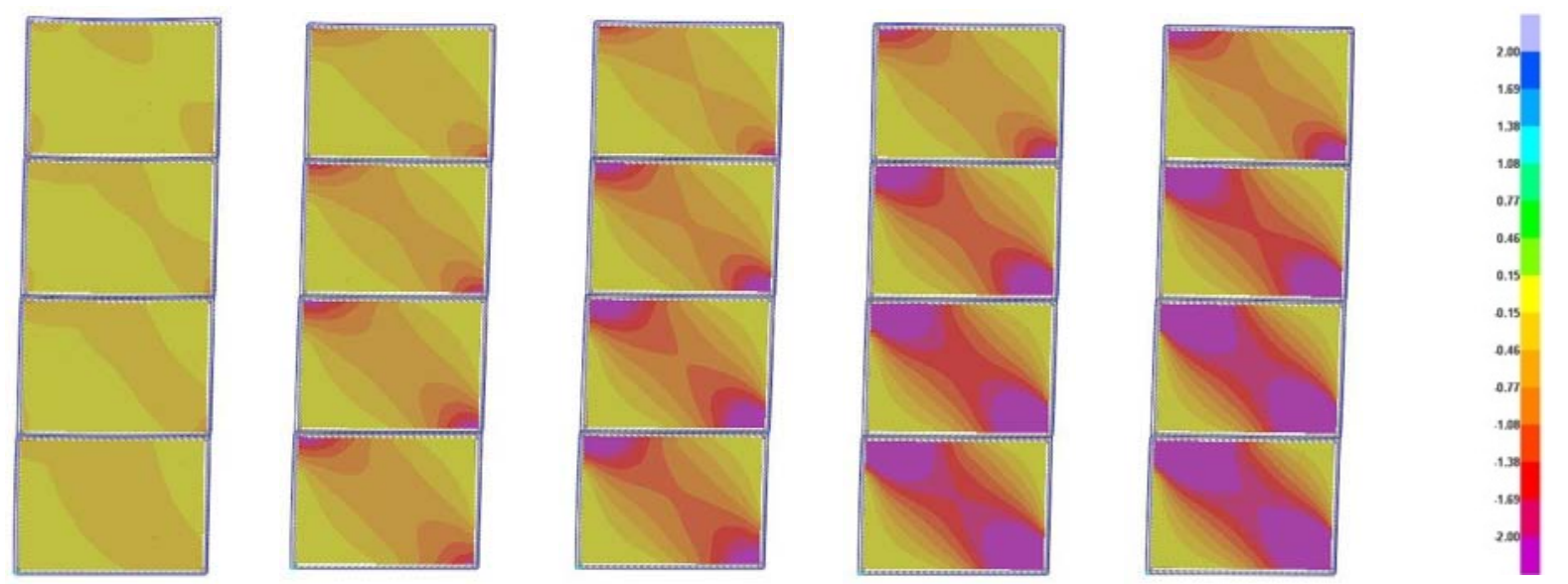

Fig. 4 - Evolution of principal compression stresses, $\operatorname{Smin}\left(\mathrm{N} / \mathrm{mm}^{2}\right)$ in the masonry panel 
This is accompanied by an important increase of the stiffness of the building. In figure 5 the pushover curves for the bare frame and the full infill models are traced. The computed stiffness of the bare frame is 3.5 times lower than the stiffness of the infilled frame.

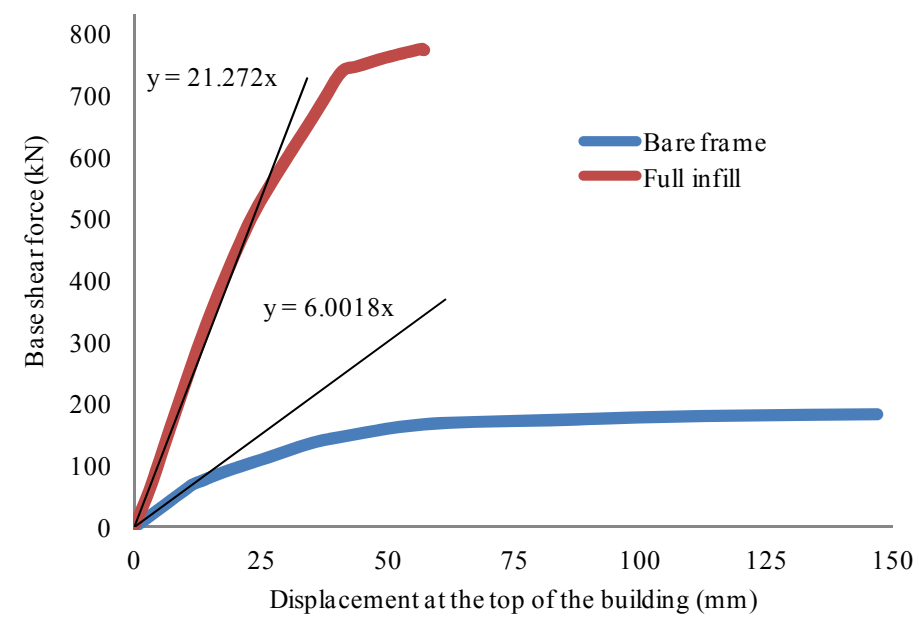

Fig. 5 - Comparison between structural behaviour for bare frame and infilled frame

For the bare frame, the fundamental period is $0.6 \mathrm{~s}$ and the maximum lateral load is $180 \mathrm{kN}$. For the infilled frame, the maximum load is $800 \mathrm{kN}$. The maximum displacement of the bare frame is $150 \mathrm{~mm}$, while for the infilled frame it is only $60 \mathrm{~mm}$. For the infilled frame, the triggering event that stopped the displacement was the failure of the concrete column in tension. For the final state, the computed von Mises stress, SVM, at the corners of the masonry panels reaches values higher than $8.3 \mathrm{MPa}$, up to $19 \mathrm{MPa}$. This means that corner crushing failure can occur prior to failure of the column, in particular for hollow bricks. Still, as masonry compressive strength can sometimes be much higher than the strength computed using Eurocode formulas [27], the column failure criterion was considered

\section{Influence of construction gaps on the behaviour}

The influence of physical gaps between the masonry and the frame on the nonlinear response of the structure is analysed. These gaps could be required by design in order to ensure separation or they could be a result of poor construction of the partition walls. The same dimensions of the gaps were considered on top of the panel as well as on its sides.

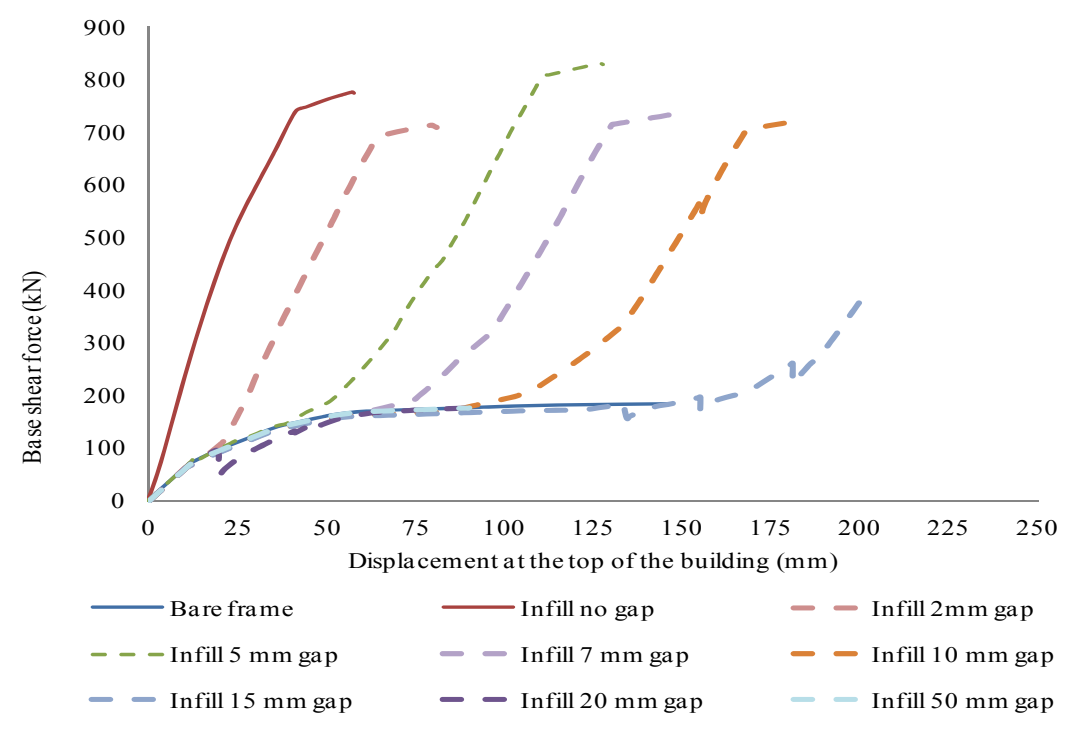

Fig. 6 - Influence of physical gap between frame and infill on the nonlinear response 
The results show that it is very important to account for such eventual gap because the overall behaviour of the frame is significantly affected. The behaviour of the structure corresponds to that observed in experimental testing [29]. While there is no contact between the frame and the infill, the structure behaves exactly as the bare frame. After contact, there is a sudden rise in stiffness and the structure behaves similar to the fully infilled one. For the analysed building, 20 $\mathrm{mm}$ gaps are sufficient to ensure that there is no interaction between the frame and the infill which could influence structural behaviour.

\section{Comparison between the equivalent diagonal and the full panel}

The response of the building when only a compression diagonal is taken into account was considered. For the frame diagonals, several models were analysed, in which the equivalent width varies from $\mathrm{D} / 4$ to $\mathrm{D} / 12.5$, where $\mathrm{D}$ represents the length of the diagonal.

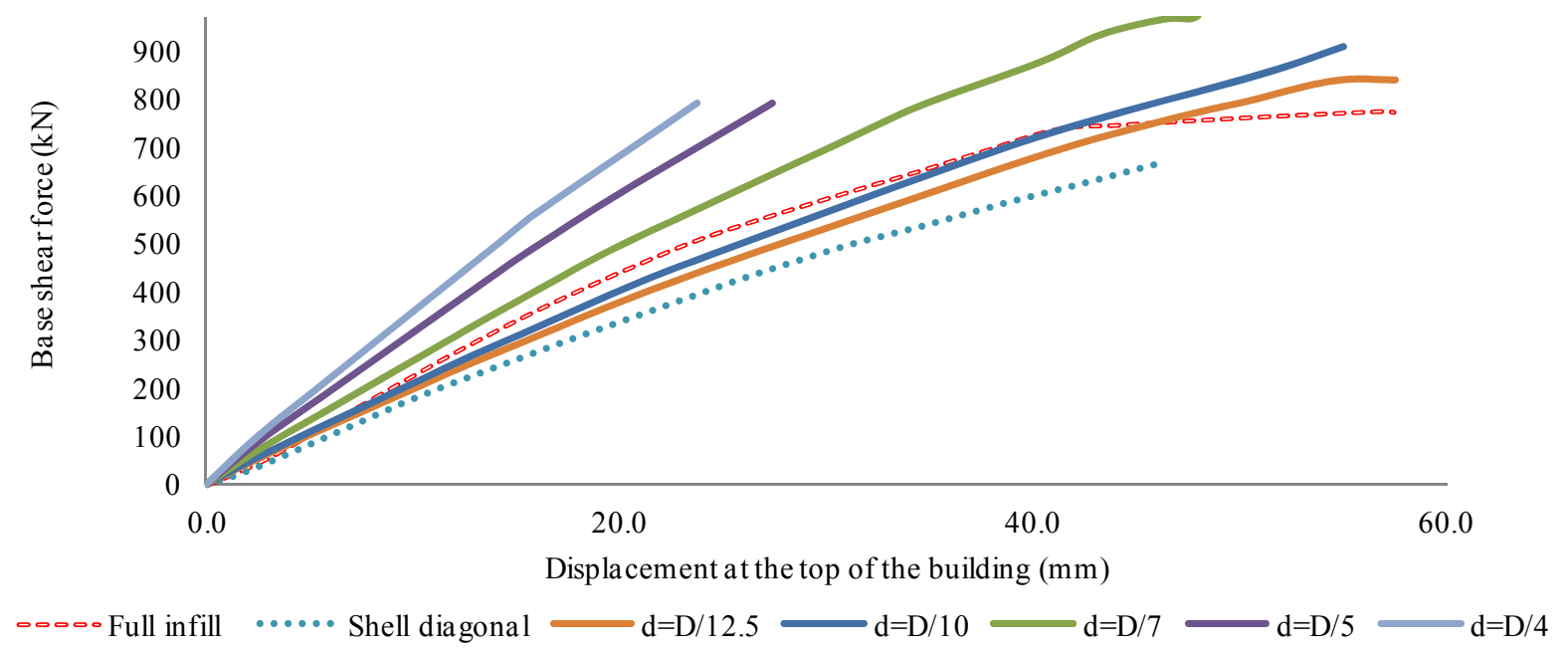

Fig. 7 - Response of the building for various configurations considered for the diagonal strut

The model with shell elements only on the diagonal of the panel does not correctly predict the observed stiffness (Figure 7). For the models with frame diagonals, the $\mathrm{d} / 10$ diagonal best expresses the stiffness of the building for the studied case.

Yet the equivalent diagonal models fail to estimate the forces in the elements. In figure 8 , the evolution of axial and shear forces and bending moments in the +3.00 beam near its intersection with the column are traced. If the axial force is correctly predicted, there is an important difference related to predicting bending moment and shear force. In particular shear force is important, because it could lead to brittle failure. In the equivalent frame model the shear remains practically constant through all the loading phase, while in the shell model the shear force rises four times, with opposite sign to the initial value (Figure 8).
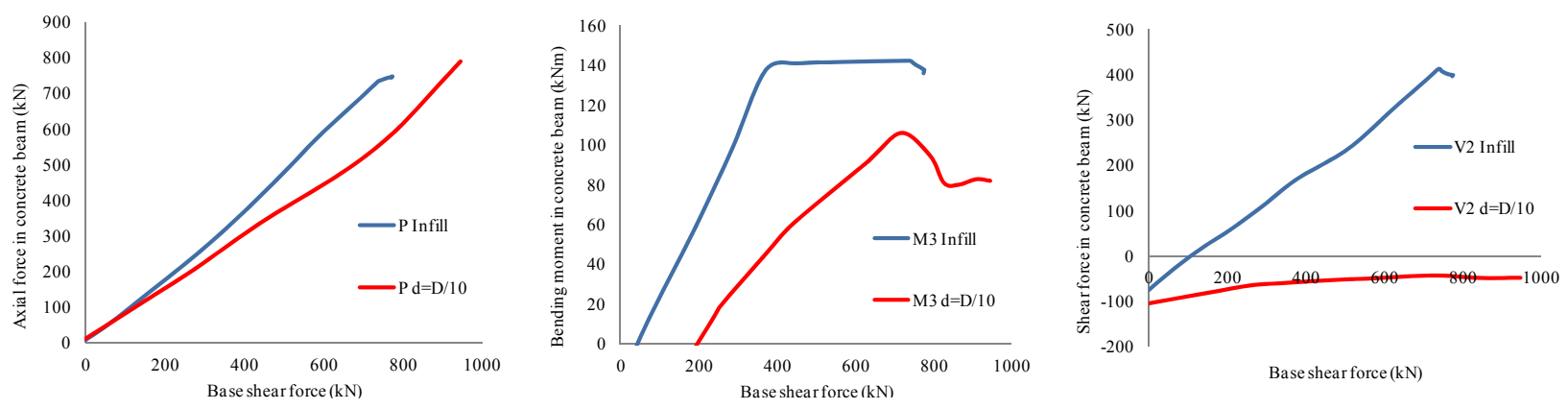

Fig. 8 - Forces in the +3.00 beam. Comparison between the single frame diagonal and the full infill models 


\section{Influence of the openings on the structural behaviour}

The effects that window openings in the infill have on the response of the structure were analysed. As the window prevents the formation of a direct diagonal strut, inclined struts appear above and below the windows as shown in figure 9. This leads to a high increase in stresses around the angles of the windows. Failure patterns observed in experimental tests [8, 25, 30, 31] indicate that these areas are most likely to fail first and should be carefully designed.
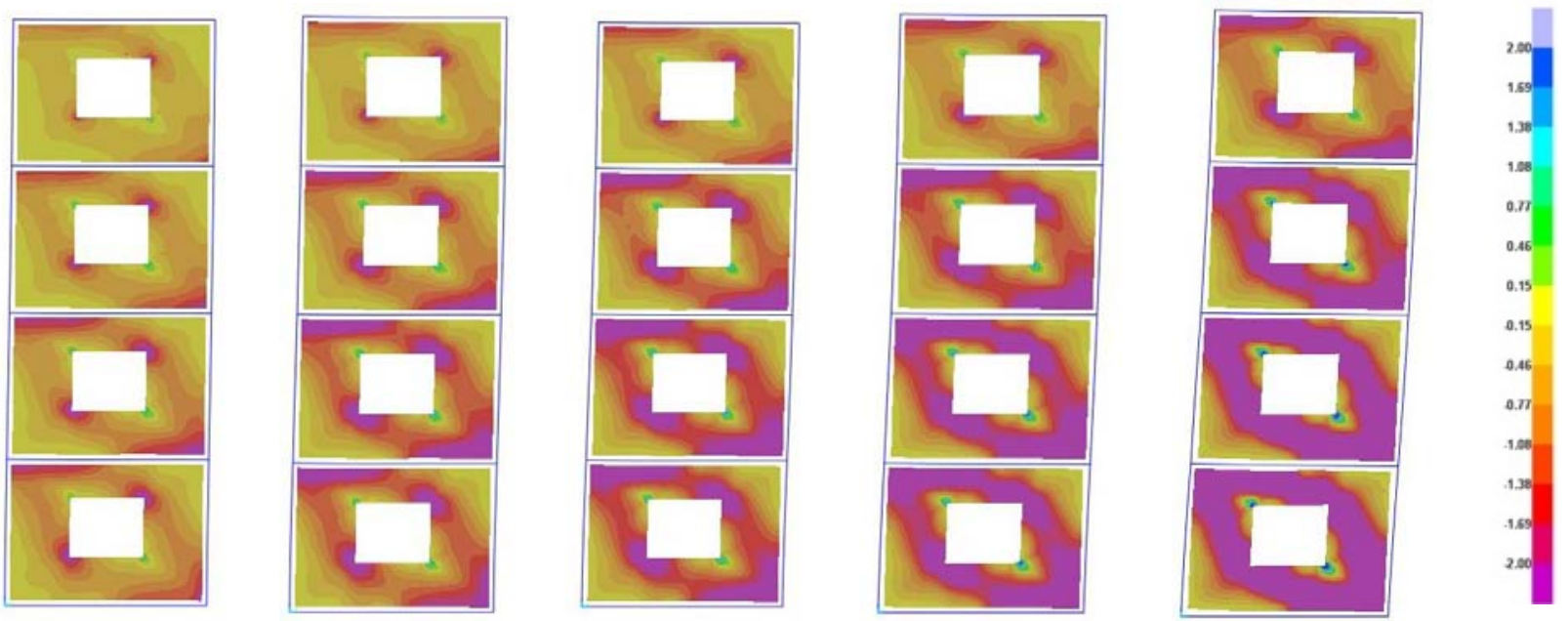

Fig. 9 - Evolution of principal compression stresses, Smin $\left(\mathrm{N} / \mathrm{mm}^{2}\right)$ around window openings

For the door openings, a similar pattern is observed. A high concentration of compression stresses appears near the top angle of the opening. For the central door opening (Figure 10), the diagonal strut acts more on the compressed column, when compared to the full infill model, with an increase in the shear force. A similar effect is observed at the top of the storey, where the diagonal compresses the beam. Under normal circumstances, the central part of the beam has little shear reinforcement provided, given that the shear value is low. As a result, the effect can be particularly dangerous and requires careful consideration. For the side door opening (Figure 11), the increase in shear appears near the joint.

Failure patterns observed in experimental tests $[8,25]$ correspond to this behaviour highlighted by the numerical models.
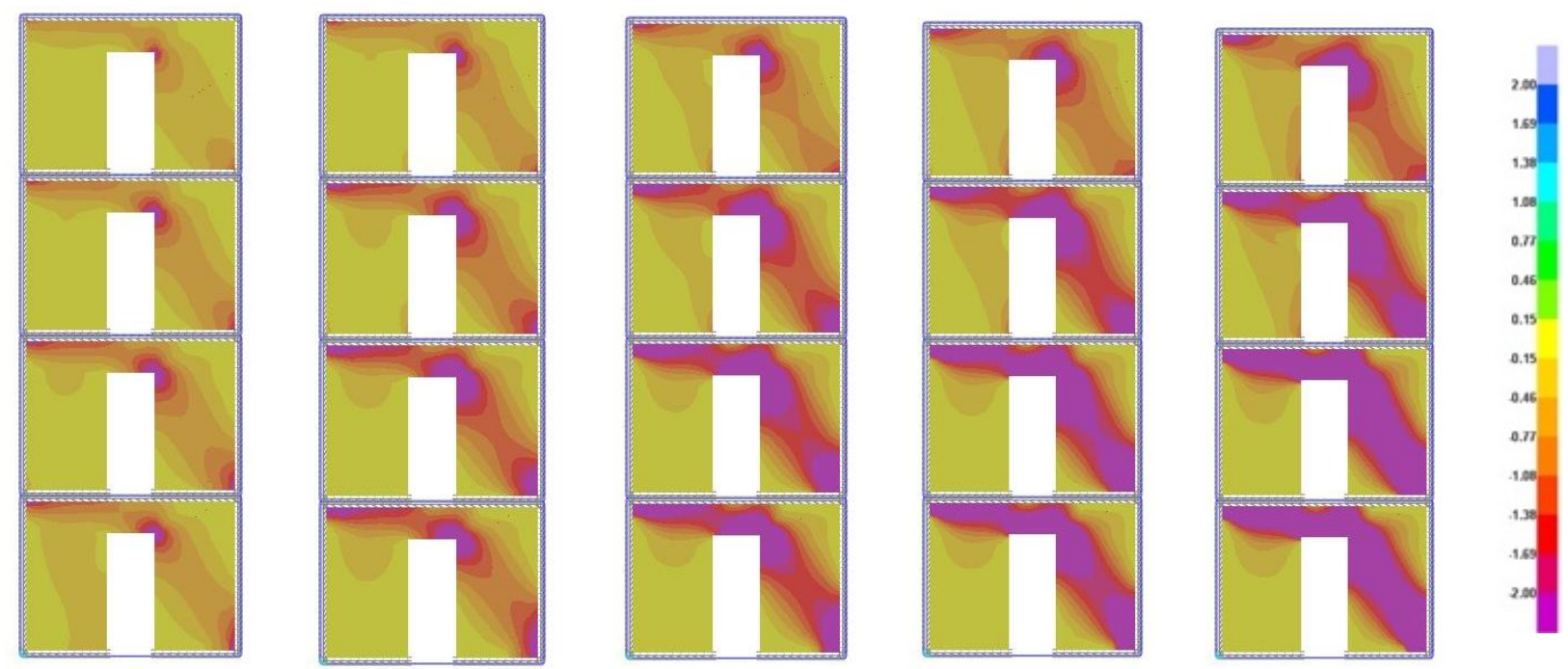

Fig. 10 - Evolution of principal compression stresses, $\operatorname{Smin}\left(\mathrm{N} / \mathrm{mm}^{2}\right)$ around central door opening 

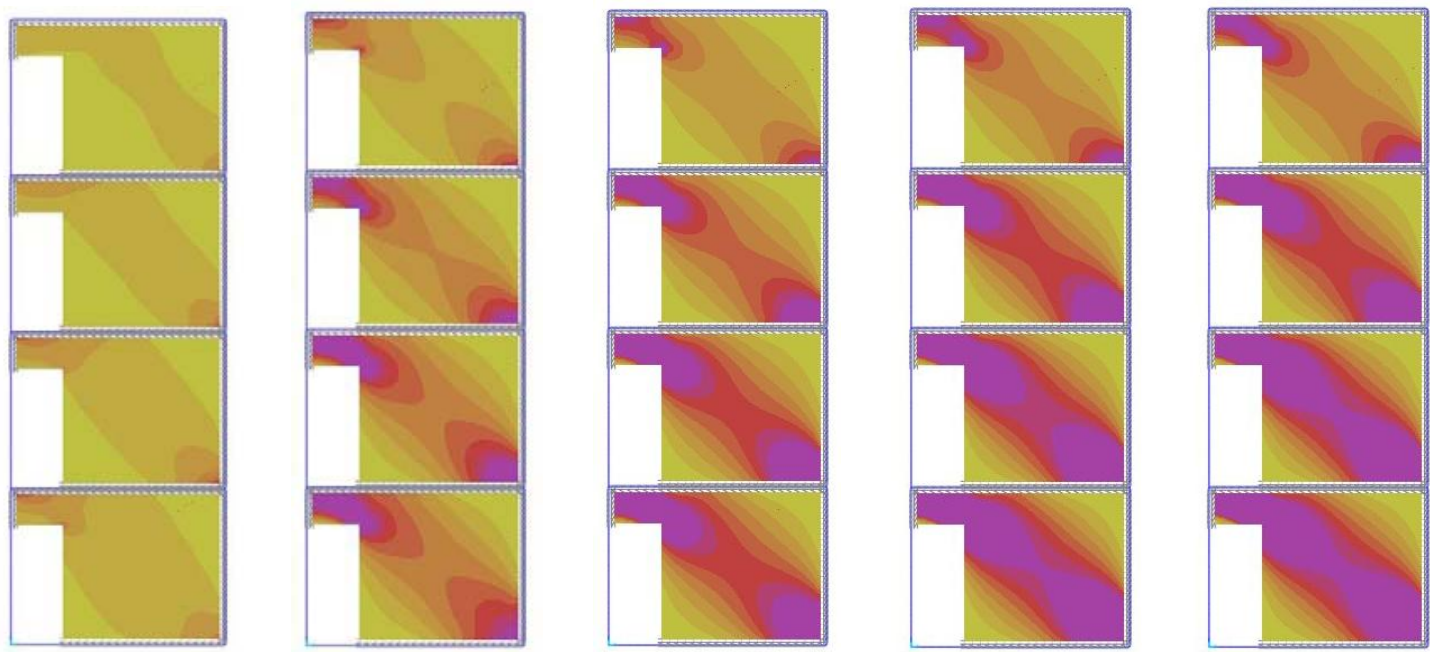

Fig. 11 - Evolution of principal compression stresses, $\operatorname{Smin}\left(\mathrm{N} / \mathrm{mm}^{2}\right)$ around lateral door opening

The central door openings lead to a significant decrease of the building stiffness, while the decrease for windows and lateral doors is minimal (Figure 12).

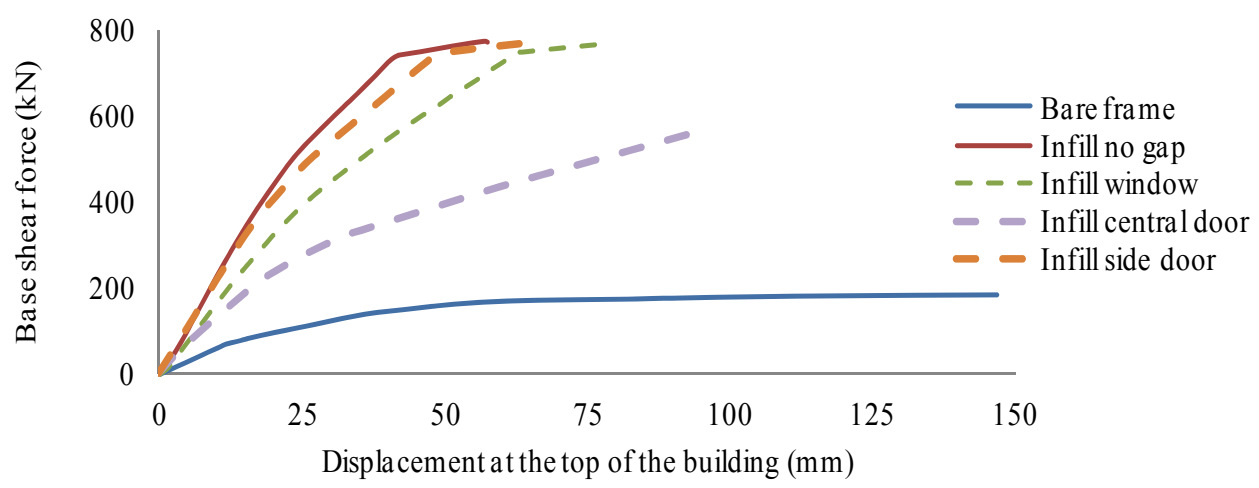

Fig. 12 - Influence of openings in the infill on the structural response

\section{Soft storey mechanism}

For the soft storey model, the nonlinear static pushover analysis shows that increasing lateral loads leads to development of plastic hinges only in the ground floor columns (Figure 13).
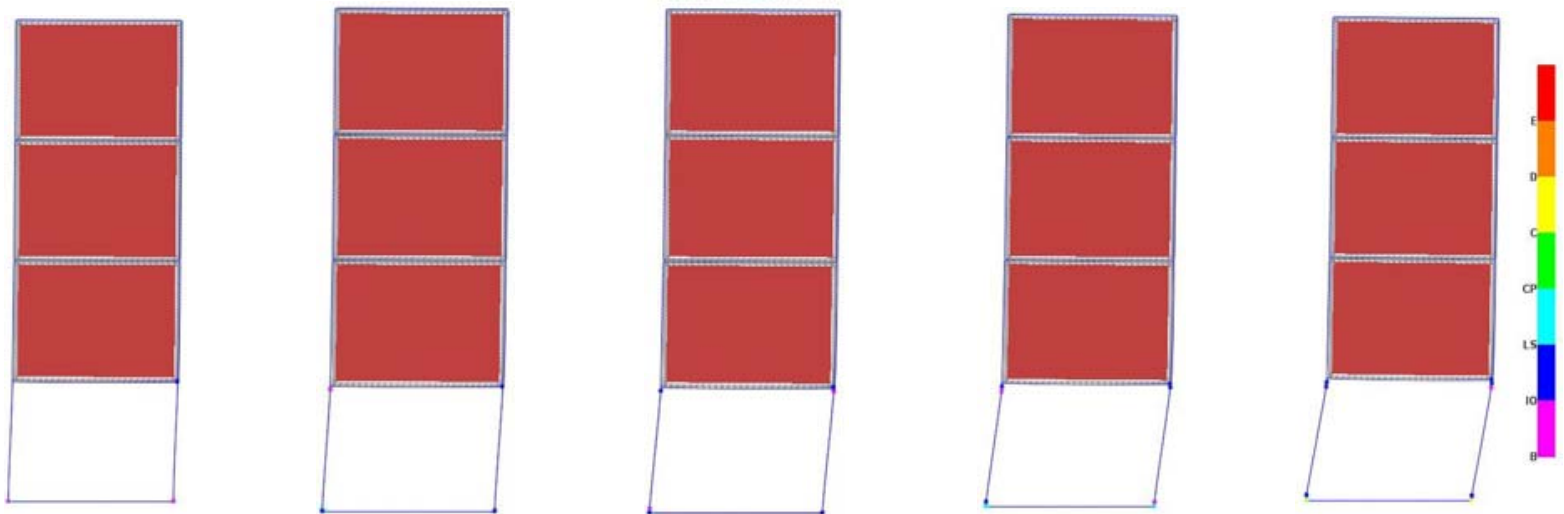

Fig. 13 - Development of plastic hinges in the RC elements for the soft storey model

This decreases the post-elastic deformation capacity of the building by more than $50 \%$. As shown in Figure 14, the ultimate displacement predicted by the soft-storey model is $66 \mathrm{~mm}$, while for the bare frame model the ultimate displacement is $147 \mathrm{~mm}$. 


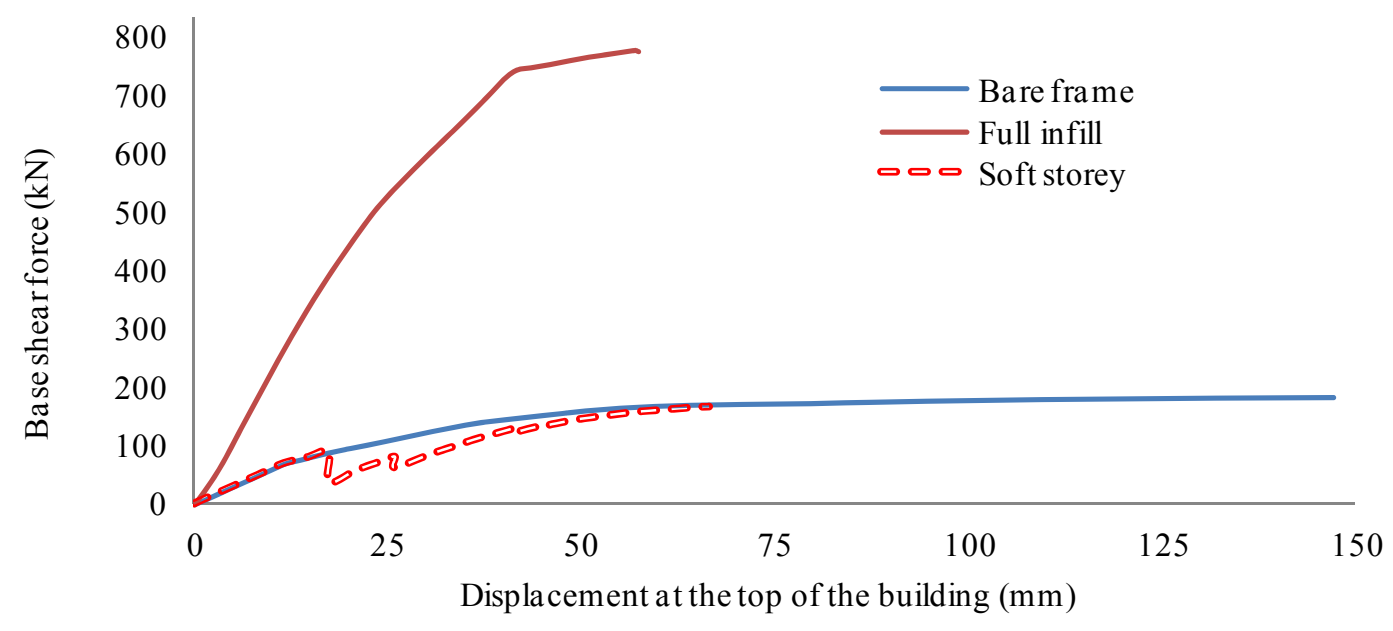

Fig. 14 - Soft storey structural response

\section{Conclusions}

The results obtained from the numerical models show the important influence of the masonry infill on the RC frame behaviour for in-plane lateral loads.

The numerical simulations indicate that masonry infill highly increases the stiffness of the structure, up to 3.5 times when compared to the bare frame structure. The openings in the infill influence this effect, particularly door openings.

Masonry infill also increases the strength of the structure (as long as the seismic demand does not exceed the deformation capacity of the infills). Still, the presence of gaps between the infill and the frame can limit this beneficial effect of masonry. For the studied case, separating the infill from the frames by $20 \mathrm{~mm}$ gaps at the top and on the sides is sufficient to allow the frame to freely deform, similarly to the no-infill case.

Simple modelling with equivalent diagonal struts, which carry loads only in compression, is able to simulate the global seismic response of the infilled frames. The dimension of the equivalent strut proposed by the current Romanian seismic code, $d=D / 10$ offers a very good estimate of the building stiffness for the studied case. But diagonal frame models cannot estimate the evolution of forces in frame members. Shear forces, which could lead to brittle failure, are particularly underestimated.

The window and door openings in the infill lead to the formation of inclined struts with high concentration of stresses near the corners of the openings, which could lead to failure in the masonry.

The soft storey mechanism is particularly dangerous, as the displacement capacity of the building is reduced to less than $50 \%$ when compared to the bare frame. This could result in premature failure of the building.

It is extremely important to take these possible failure mechanisms into account when designing new buildings.

\section{References}

[1]. Kam, W. Y., Pampanin, S., Dhakal, R. P., Gavin, H., \& Roeder, C. W. (2010). Seismic performance of reinforced concrete buildings in the September 2010 Darfield (Canterbury) earthquakes. Bulletin of New Zealand Society of Earthquake Engineering. Vol. 43, No. 4, pp. 340-350

[2]. Dhakal, R.P. (2010) Damage to Non-Structural Components and Contents in 2010 Darfield Earthquake. Bulletin of the New Zealand Society of Earthquake Engineering. Vol. 43, No. 4, pp. 404-411. 
[3]. Hermanns, L., Fraile, A., Alarcón, E., \& Álvarez, R. (2014). Performance of buildings with masonry infill walls during the 2011 Lorca earthquake. Bulletin of Earthquake Engineering. Vol. 12, No. 55, pp. 1977-1997. DOI 10.1007/s10518-013-9499-3

[4]. Li, B., Wang, Z., Mosalam, K. M., \& Xie, H. (2008). Wenchuan earthquake field reconnaissance on reinforced concrete framed buildings with and without masonry infill walls. The 14th World Conference on Earthquake Engineering. Beijing, China.

[5]. Zhao, B., Taucer, F., \& Rossetto, T. (2009). Field investigation on the performance of building structures during the 12 May 2008 Wenchuan earthquake in China. Engineering Structures, Vol. 31, No.8, pp. 1707-1723.

[6]. Žarnić, R., Gostič, S., Crewe, A. J., \& Taylor, C. A. (2001). Shaking table tests of 1: 4 reduced-scale models of masonry infilled reinforced concrete frame buildings. Earthquake engineering \& structural dynamics. Vol. 30 No. 6, pp. 819-834.

[7]. Calvi, G. M., Bolognini, D., \& Penna, A. (2004). Seismic performance of masonry-infilled RC frames: benefits of slight reinforcements. Invited lecture to Sísmica 6, pp. 14-16.

[8]. Stavridis, A. (2009). Analytical and experimental study of seismic performance of reinforced concrete frames infilled with masonry walls. Doctoral dissertation. University of California, San Diego, USA.

[9]. TUCEB (2013) Code for seismic design - Part I - Design rules for buildings. P100-1/2013. Bucharest

[10]. CEN (2004) Eurocode 8: Design of structures for earthquake resistance - Part 1: General rules, seismic actions and rules for buildings. EN 1998-1:2004. Brussels

[11]. Polyakov, S. V. (1960). On the interaction between masonry filler walls and enclosing frame when loaded in the plane of the wall. Earthquake engineering. pp. 36-42.

[12]. Paulay, T., \& Priestley, M. J. N. (1992) Seismic design of reinforced concrete and masonry buildings. John Wiley \& Sons, Inc, Hoboken, New Jersey. pp 768.

[13]. Smith, B. S. (1962). Lateral stiffness of infilled frames. Journal of the Structural Division, ASCE. Vol. 88 No. 6, pp. 183-199.

[14]. Crisafulli, F. J. (1997). Seismic behaviour of reinforced concrete structures with masonry infills.

[15]. Chrysostomou, C. Z., Gergely, P., \& Abel, J. F. (2002). A six-strut model for nonlinear dynamic analysis of steel infilled frames. International Journal of Structural Stability and Dynamics. Vol. 2, No.3, pp. 335-353.

[16]. Crisafulli, F. J., \& Carr, A. J. (2007). Proposed macro-model for the analysis of infilled frame structures. Bulletin of the New Zealand Society for Earthquake Engineering. Vol. 40, No.2, pp. 69-77.

[17]. Rodrigues, H., Varum, H., \& Costa, A. (2010). Simplified macro-model for infill masonry panels. Journal of Earthquake Engineering. Vol. 14 No.3, pp.390-416.

[18]. Mallick, D. V., \& Severn, R. T. (1967). The behaviour of infilled frames under static loading. ICE Proceedings. Vol. 38, No. 4, pp. 639-656

[19]. Te-Chang, L., \& Kwok-Hung, K. (1984). Nonlinear behaviour of non-integral infilled frames. Computers \& structures. Vol. 18 No. 3, pp. 551-560.

[20]. Asteris, P. G. (2003). Lateral stiffness of brick masonry infilled plane frames. Journal of Structural Engineering. Vol. 129 No.8, pp. 1071-1079.

[21]. Mehrabi, A. B., \& Shing, P. B. (1997). Finite element modeling of masonry-infilled RC frames. Journal of structural engineering. Vol. 123, No.5, pp. 604-613.

[22]. Attard, M. M., Nappi, A., \& Tin-Loi, F. (2007). Modeling fracture in masonry. Journal of Structural Engineering. Vol. 133, No.10, pp. 1385-1392.

[23]. Stavridis, A., \& Shing, P. B. (2010). Finite-element modeling of nonlinear behavior of masonry-infilled RC frames. Journal of structural engineering. Vol. 136, No. 3, pp. 285-296.

[24]. El-Dakhakhni, W. W., Elgaaly, M., \& Hamid, A. A. (2003). Three-strut model for concrete masonryinfilled steel frames. Journal of Structural Engineering. Vol. 129, No.2, pp. 177-185.

[25]. Asteris, P. G., Kakaletsis, D. J., Chrysostomou, C. Z., \& Smyrou, E. E. (2011). Failure modes of In-filled frames. Electronic Journal of Structural Engineering. Vol. 11, No. 1, pp. 11-20.

[26]. CEN (2004) Eurocode 2: Design of Concrete Structures: Part 1-1: General Rules and Rules for Buildings. EN 1992-1-1:2004. Brussels.

[27]. Kaushik, H. B., Rai, D. C., \& Jain, S. K. (2007). Stress-strain characteristics of clay brick masonry under uniaxial compression. Journal of materials in Civil Engineering, Vol. 19, No. 9, pp. 728-739.

[28]. CEN (2005) Eurocode 6: Design of masonry structures-Part 1-1: General rules for reinforced and unreinforced masonry structures. EN 1996-1-1:2005+A1:2012. Brussels.

[29]. Lin, K., Totoev, Y. Z., Liu, H. J., \& Page, A. W. (2014). Modeling of dry-stacked masonry panel confined by reinforced concrete frame. Archives of Civil and Mechanical Engineering. Vol. 14, No.3, pp. 497-509.

[30]. Chen, X., \& Liu, Y. (2015). Numerical study of in-plane behaviour and strength of concrete masonry infills with openings. Engineering Structures. Vol. 82, pp. 226-235.

[31]. Koutromanos, I., Stavridis, A., Shing, P. B., \& Willam, K. (2011). Numerical modeling of masonry-infilled $R C$ frames subjected to seismic loads. Computers \& Structures. Vol. 89, No.11, pp. 1026-1037. 